\title{
How to Increase the Income of Cocoa Farmers through the Development of Cocoa Products?
}

\author{
Mike Triani ${ }^{1}{ }_{\text {,Marta Dinata }}{ }^{2}$,Andria Ningsih ${ }^{3}$ \\ ${ }^{1}$ Universitas Negeri Padang, Padang and Indonesia $₫ \underline{\text { Miketriani@fe.unp.ac.id }}$ \\ ${ }^{2}$ Universitas Lancang Kuning, Riau and Indonesia $₫ \underline{\text { Martadinata40@gmail.com }}$ \\ ${ }^{3}$ STIE Haji Agus Salim Bukittinggi, Bukittinggi and Indonesia $\bowtie$ Andrianingsih56@gmail.com
}

\begin{abstract}
Cocoa is one of plantation commodities main West Sumatera also play a role important as producer regional foreign exchange, and as provision of employment opportunities and source of income for farmers. Demand cocoa the world is still very high which annually increased .Cooperatives cocoa 'Mandiri Prima' is one of the most potential cooperative in Lima Puluh Kota district, Tanah Datar regency. Cooperatives cocoa "Mandiri Prima" has a member of as many as 46 one who reliable in administer the estate cocoa, only processing cocoa beans was not perfect so processing cocoa beans feasible for marketing. A method of activities will be implemented with group discussions and understanding fodder for participants a member of farmers cocoa. The discussion groups and for the delivery of material, it turns out its participants stated that they failed to in implementing fermentation cocoa beans becoming brown quality. It was because they did not understand technically the process. It becomes one of the problems for the government to increase production cocoa in the area. For that we need to review the how product development cocoa beans in regency land these flat in order to increase farm incomes cocoa and can increase the value of valueadded production.
\end{abstract}

Keywords: value added production, product, and income

\section{Introduction}

Cocoa is one of the most potential plantation commodities in West Sumatera also played an important role as foreign exchange earning regions, those that provide employment opportunities and a source of income for farmers. Demand the world cocoa is still very high which annually has been increase. The needs of the world cocoa a year reached 6.7 million tons just can be fulfilled 2.5 million. It means, around 4 million tons more to meet the needs of the market that continues to increase, so it could still be an opportunity for Indonesia specially in West Sumatera to be able to continue to increase and producing stuff. Most of areas in West Sumatera have climate suited to the growth cocoa and land are available. In addition commodity prices cocoa until now is too stable, cocoa can also be intercropped with coconut commodities in West Sumatera more than 91.000 ha.

As stated by Mr. Erinaldi one of the Chairman of Farmers Group called Cocoa Farmer Group Tani Batu Lantai Stating that they are very short of human resources capable of processing cocoa beans into products that can increase income or as a value added cocoa beans from cocoa beans. He also said that it requires the government's efforts to provide a tool for processing cocoa beans which will certainly be very helpful at the production of better.

The government of West Sumatera prioritizes cocoa the main program that is carried out during the period of 2, 2006 to 2010 and the year 2010 to 2015. Even until the year of 2015 the target of landbuying of cocoa at least 200,000 ha .The provincial government and the central government began a program to develop the cocoa .If the pattern cocoa to 200,000 ha successfully will put West Sumatera 
to be the production center of cocoa in Indonesia. Under this condition, it hopes the income of farmers are going to be increased and close to welfare.

Table 1 Broad fields, broad harvesting and cocoa production in Tanah Datar district :

\begin{tabular}{|c|c|c|c|c|c|}
\hline \multicolumn{3}{|c|}{ Subdistrict } & $\begin{array}{c}\text { Wide } \\
\text { harvested }\end{array}$ & Production & Average \\
\hline 1 & \multicolumn{2}{|l|}{$\mathrm{X}$ Koto } & & & \\
\hline 2 & \multicolumn{2}{|l|}{ Batipuh } & 73,26 & 56,00 & 0,76 \\
\hline 3 & \multicolumn{2}{|l|}{ Batipuh Selatan } & 205,75 & 153,99 & 0,75 \\
\hline 4 & \multicolumn{2}{|l|}{ Pariangan } & 95,50 & 80,00 & 0,84 \\
\hline 5 & \multicolumn{2}{|l|}{ Rambatan } & 1110,50 & 1121,83 & 1,01 \\
\hline 6 & \multicolumn{2}{|l|}{ Lima Kaum } & 332,37 & 300,99 & 0,91 \\
\hline 7 & \multicolumn{2}{|l|}{ Tanjung Emas } & 271,35 & 265,05 & 0,98 \\
\hline 8 & \multicolumn{2}{|l|}{ Padang Ganting } & 175,20 & 161,51 & 00,92 \\
\hline 9 & \multicolumn{2}{|l|}{ Lintau Buo } & 124,45 & 119,55 & 0,96 \\
\hline 10 & \multicolumn{2}{|l|}{ Lintau Buo Utara } & 765,50 & 780,71 & 1,02 \\
\hline 11 & \multicolumn{2}{|l|}{ Sungayang } & 232,50 & 236,05 & 1,02 \\
\hline 12 & \multicolumn{2}{|l|}{ Sungai Tarab } & 188,38 & 184,63 & 0,98 \\
\hline 13 & \multicolumn{2}{|l|}{ Salimpaung } & 149,50 & 143,25 & 0,96 \\
\hline 14 & \multicolumn{2}{|l|}{ Tanjung Baru } & 216,50 & 212,00 & 0,98 \\
\hline \multirow{5}{*}{\multicolumn{2}{|c|}{ Tanah Datar }} & 2015 & 3949,26 & 3821,65 & 0,91 \\
\hline & & 2014 & 3340,39 & 2804,04 & 0,84 \\
\hline & & 2013 & 3229,00 & 2322,04 & 0,72 \\
\hline & & 2012 & 2381,04 & 1287,28 & 0,54 \\
\hline & & 2011 & 1525,09 & 794,50 & 0,52 \\
\hline
\end{tabular}

Source: Batusangkar in figures 2015

Through cocoa development program every year millions of superior cacao seeds, are given free to the community of West Sumatera to be planted on the terrain. This program was funded by provincial budget, the state and district budget. If broad cocoa in 2006 only 25.042 ha, in 2012 broad cocoa already reached 137.355 ha, while production resulting in 2006 only 16,244 tons, jumped to 69.281 tons in 2012. Increase in extent garden this cocoa would bring a positive impact on the increase in the income of the community welfare as well as farmers and probably can also reduce the poverty rate in West Sumatera. Because as much as $71.8 \%$ of the poor in West Sumatera in rural areas and a large proportion were farmers

\section{Methods}

In the method section, was used group discussions through to delivery matter to the farmers cocoa. Training will be conducted by five people instructors namely material which is to be forum was with regard to: 1 for the delivery of material about the potential market of cocoa .2) increasing the added value production .3) product development, 4) packaging products and product marketing .5) processing cocoa beans into finished products .In addition methods used to solve problems partner is:

1. For the delivery of material the field of science economic, management and marketing

2. Comprises the group discussion of farmers cocoa.

3. To apply the concept of material the field of science economic, management and marketing in processing cocoa beans.

4. Creates a value added product from the seeds of cocoa. 
5 Packaging and selection brand products. 6. The installation of label the and patent to the processed products cocoa beans are already in the process of by the farmers

\section{Results}

Based on the devotion to the community through training processing products cocoa beans through product development for households farmers cocoa in Tanah Datar regency, namely from 16 to $17^{\text {th }}$ September 2017. This event was joined by farmers of cocoa which consisted of 30 people, consisting of the members of the cooperative spread in Regency at Tanah Datar. The delivery of material was by the sources of potential market of cocoa. In Cubadak district, five people have many subspecies potential for development cocoa beans, besides texture good ground this area also having farmers superior and reliable in managing cocoa development. Then, this area need to be central production of cocoa, it takes cooperation and motivation from the local regional government to think for planning the potency advancement cocoa this.

Value added production was one effort to the provision of additional value for businesses. Other commodities of cocoa is through the existence of the processing industries so that these products have the value added like export commodities. Considering that of export commodities no longer sent as a raw material. The presence of cocoa processing industry in the country can be used as anticipation if prices decrease in the world, if farmers manage it in the country it can be exported at higher price.

Next, second matter is about the enhancement of value added production. Technically in the field, farmers extremely scrupulous in managing cocoa, but farmers still have the skills and science are low in understanding the concept of value added production .Based on the results of its field observation, it turns out that farmers have done only product marketing cocoa beans to the market without any management process the production of cocoa beans. It means farmers here did not know that if cocoa beans in sports be cocoa powder, then in sports be chocolate bars or lozenge of material brown of the price offer to market can be in the value of greater than his just selling cocoa beans course to the market .Formerly, from the observation some of the farmers already have been trying to put fermented cacao beans to process of drying so that will be able to destroy it in to be used as cocoa powder. But, unfortunately farmers experiencing the failure of a conducting the process of fermentation, Because of a lack of knowledge and skill in this process. Then the observation the work of the next trying to articulate matter process of making brown powder the great thing about cocoa beans are have been through fermentation processes right.

In theory, it will improve the value added production would be needed good processing process. According to research on computation added value has been conducted on small scale businesses processing (cocoa beans by 2012 of value added) cocoa beans in Madiun district, East Java .The senses analyze add value to products of processed cocoa to be a semi or chocolate brown finished the fat, brown powder, brown and pasta. The product is produced using raw materials and other input contributions in the same amount of. But, there is the production of raw materials in the cocoa beans used will be turned into brown paste, brown powder, and fat brown separately the process of production and only be turned into fat and powdered brown only once it resulted in processing produksi.hal process cocoa beans was set to fat brown and just brown powder .

The third material was on product development. About product development, it cannot be separated from all production process. If farmers have through all production processes so farmers can continue to higher stage product development that began in processing cocoa beans to powder brown, then brown powder used as be a variety of foods brown various think and a brown form being in demand by consumers. For product development, it needs skill from the farmers, besides increasing income it also can be used as a source of regional revenue for an area of land flat. At the product development this farmers in this area only is be able to create brown powder underperforming, of this product not able to compete in the market. It means products can only be consumed by household farmers cocoa or society immediate area that is all.

The theory of kotler and armstrong 1996 on product development is through product development is a strategy to growth of the company by offering of a new product or modified to a 
segment of market now. So, it can be seen that the development of the product is an activity enterprises to meet the needs of those who always changed. Company it must mix their decision to function marketing other between the new products. Usually the marketing coordinate duty on the inside of the company informally. This has led to the growing importance of the product development strategy for marketing an enterprise. All products will undergo cycle products, product development should be done a sustainable by any company during their products. To avoid saturation consumers to their products, so that the product was not experienced stage decline, who would result in survival an enterprise.

The fourth is about packaging products and marketing. The key to make a design packaging is packaging should be simple, functional and create an emotional response. Packaging must be able to attract attention visually, emotionaly and rationaly. According to research, of all activities sensing people are big is sensing through sight or visually. Because of that, elements graphic from the pack among other: color, the form of, brand, illustration, letters and the layout is element visual have a role in largest in the process of delivery of message by fluoresce (visually communication). To successful, so appearance a bundle should have attractiveness. Attractiveness on packaging can be inducted into two kinds, namely the pull visual (aesthetic) attraction and practical (functional).

Traditionally, function primary the pack is to load and protect products. But in recent times this, many factors that makes packaging be instrumental marketing important. The increasing competition and disorderly a rack a retail store, means that packaging must now do a lot of duty sales, attract attention, outlines products, and even make a sale. Company realized influence from the pack good that consumers know company or owns the quickly. Develop packaging that is better for new product take a lot of decision-making. First, companies should draw up the concept of packaging, who specifies how to packaging it is supposed to be or what one should be doing by packaging for products Do packaging that only function provide protection products, introduce a method of packaging new, or other thing? Then, the decision must be made to determine the elements specific from the packing, such as size, the form of, material, color, text, and trademarks. Various this elements must work together to support position the product and marketing strategies. Packaging has to be consistent with advertising, pricing, and distribution of a product.

\begin{tabular}{|l|l|l|l|}
\hline $\begin{array}{l}\text { Downstream Product } \\
\text { Development for Cacao } \\
\text { Farmer's Household in } \\
\text { Tanah Datar District }\end{array}$ & $\longrightarrow \begin{array}{l}\text { Process of cocoa beans } \\
\text { into downstream } \\
\text { products }\end{array}$ & $\longrightarrow \begin{array}{l}\text { Increased knowledge and } \\
\text { ability to develop by } \\
\text { creating downstream cocoa } \\
\text { bean products }\end{array}$ \\
\hline
\end{tabular}

\section{Conclusions}

Cocoa is the result of the earth that must be cultivated and there should have been the touch technology so that produce quality seeds good becoming brown, this chocolate also can compete in national and international market. Other than the processed products capable of producing quality of these farmers important to her knowledge and experience being many created the processed products that goods as well as being able to compete with the international. Besides the motivations of the head of cooperatives, important for farmers in along with same the government provide the motivation to take part in the support and help from technology so that farmers at Cubadak district, Limo Kaum regency, Tanah Datar will understand using the technology, and understand the meaning of important creates a product downstream from cocoa beans into a product with the most potential in the area.

The success of the other measured income from the itself must also followed by the productivity workers in a itself. Instead of creating products, it is also vital with farmers understanding how to put the product well marketable. Because besides created added value production the activity of designing and producing is as a forum to a product. Packaging designed with good can build brand equity and encourage sales. Packaging is the part first products faced by buyers and able to attract 
buyers or get rid of. A label might include gallows simple who affixed to products or images designed in elaborate and become part of the packaging. Label can carry the name brand alone, or large amounts of information. Guarantee (warranties) is official statement product performance expected by the manufacturer

\section{References}

Alma, B. (2011). Kewirausahaan. CV Alfabeta. Bandung.

Bawesdan, A, R.(1997).Sumber daya manusia indonesia sebagai penunjang pembangunan jangka panjan, Jurnal Ekonomi Pembangunan, 2(2).

Arfida, B.R. (2003). Ekonomi Sumber Daya Manusia . Ghalia Indonesia, Jakarta.

Ananta, A and Tjiptoherijanto.(1985). "Masalah Penyerapan Tenaga Kerja, Prospek dan Permasalah Ekonomi Indonesia" Sinar Harapan, Jakarta.

Ananta,A.(1993). Ciri demografis kualitas penduduk dan pembangunan ekonomi, Lembaga Demografi FE UI, Jakarta.

Badan Pusat Statistik, Sumatera Barat dalam Angka 2004 -2010, Padang.

Badan Pusat Statistik, Produk Domestik Regional Bruto 2005-2010, Padang.

Barry, M., \& Sidaway, R. (1999). Empowering through partnership-the relevance of theories of participation to social work practice. In W. Shera \& L. Wells (Eds.), Empowerment practice in social work: developing richer conceptual foundations (pp. 13-37). Toronto, Canada: Canadian Scholars' Press.

Bowen, G. A. (2006). Grounded theory and sensitizing concepts. International journal of qualitative methode 5(3) September. http: //www.ualberta.ca/-11qm/back issues/5.3/htm/bowen.htm.

Bellante , D dan Jackson, M. (1990) . Ekonomi Ketenagakerjaan. LPFE UI , Jakarta.

Dinas Koperasi Perindustrian dan Perdagangan Propinsi Sumatera Barat, Industri dan Perdagangan Sumatera Barat dalam Angka 2004-2010, Padang.

Dilana, I, A.( 2012). Pemasaran dan nilai tambah biji kakao di regency madiun, jawa timur. thesis, Sekolah Pasca Sarjana, IPB. Bogor.

Dumairy. (1996). Perekonomian Indonesia, Erlangga Jakarta.

Friedman, J. (1992). Empowerment The Political of Alternative Development. Cambridge,Massachusetts: balckwell Publisher, Three Cambridge Center.

Indriyo,G dan Agus,M. (1999). Prinsip Dasar Manajemen. Yogyakarta : BPFE.

Aimon, H.,Adry, M.R., Putri,D.Z,. \& Elida. (2013). Pemberdayaan ekonomi petani kedelai di regency solok melalui penciptaan industri rumah tangga baru. Penelitian Unggulan Perguruan Tinggi. Universitas Negeri Padang.

Karsidi. (2001). Paradigma Baru Penyuluhan Pembangunan dalam Pemberdayaan Masyarakat. Dalam Pambudy dan A.K.Adhy (ed.). Pemberdayaan Sumberdaya manusia Menuju Terwujudnya Masyarakat Madani. Bogor: Penerbit Pustaka Wirausaha Muda.

Kotler, P., Keller, K, L.(2009). Manajemen Pemasaran Ed.Ke-13 Jilid.1. Jakarta: Erlangga.

Kotler, P. (2002).Manajemen Pemasaran 1. Jakarta : Prenhallindo.

Pearce, J, A dan Richard B, R. (2007), Manajemen Strategi. Jakarta : Salemba Empat.

Sentosa, S. U., Ariusni, dan Triani, M. (2013). Model pemberdayaan rumah tangga petani dan nelayan miskin yang termarjinalkan melalui program pendidikan berwirausaha di propinsi Sumatera Barat. Hasil Penelitian Strategi Nasional Lembaga Penelitian Universitas Negeri Padang.

Suryana.(2003.) Kewirausahaan, Pedoman Praktis, Kiat dan Proses Menunju Sukses. Pen. Salemba Empat. Jakarta.

Twenge, J.M. dan Baumeister, R.F. (2004). Sosial Exclusion Increases Aggression and Self Defeating Behaviour While Reducing Intelligent Thougt and Pro-social Bdehaviour in the Sosial Physichology of Inclusion and Exclusion, Psychology Press. United Kingdom.Draf.htm,pp 222-23 